\title{
PERAN PENGELOLA PAUD DALAM MENUMBUHKAN MINAT BACA ANAK USIA DINI MELALUI PROGRAM GERAKAN NASIONAL ORANG TUA MEMBACAKAN BUKU (GERNAS BAKU)
}

\author{
Yulia Sukmanandita \\ Pamong Desa Sugihmukti - Bandung Barat - Jawa Barat - Indonesia \\ sukmananditayulia@gmail.com
}

Received: Maret, 2020; Accepted: Mei, 2020

\begin{abstract}
The fact that interest in reading early childhood in Indonesia is still very low based on the results of a survey of the Program for International Student Assessment (PISA) in 2015 shows that Indonesia is ranked 64th out of 72 countries and according to a 2015 Central Statistics Agency (BPS) survey, 91 , $4 \%$ of school-age children preferred watching television and $13.11 \%$ preferred reading. The government created the Gernas Baku Program as a movement to support initiatives and the role of families in increasing children's interest in reading through habituation at home, united paud, and in the community. This also applies in the PAUD Kasih Bunda Post. This study aims to determine how the efforts of the Cinta Bunda PAUD Institution management in fostering early childhood interest in reading through the Gernas Baku Program. Theories used in this research are Reading Interest, PAUD Institution Managers, and Gernas Baku. In this study, researchers used a descriptive method with a qualitative approach. Sources of data in this study were obtained from research samples taken from the population at the PAUD Kasih Bunda Post, namely 1 manager, 3 parents, and 3 students. The results showed that the Raw Gernas Program implemented at the PAUD Kasih Bunda Post could indeed foster children's interest in reading. Interest in reading early childhood can be seen from the child's love for books.
\end{abstract}

Keywords: Interest in reading, PAUD Institution Manager, Gernas Baku

\begin{abstract}
Abstrak
Kenyataan bahwa minat baca anak usia dini di Indonesia masih sangat rendah berdasarkan hasil survey Programme for Internasional Student Assesment (PISA) pada tahun 2015 menunjukkan bahwa Indonesia berada diurutan ke-64 dari 72 Negara dan menurut survey Badan Pusat Statistik (BPS) tahun 2015, 91,4\% anak usia sekolah lebih suka menonton televisi dan 13,11\% yang suka membaca. Pemerintah membuat Program Gernas Baku sebagai gerakan untuk mendukung inisiatif dan peran keluarga dalam meningkatkan minat baca anak melalui pembiasaan dirumah, disatuan paud, dan di masyarakat. Hal ini berlaku juga di Pos PAUD Kasih Bunda. Penelitian ini bertujuan untuk mengetahui bagaimana upaya pengelola Lembaga PAUD Kasih Bunda dalam menumbuhkan minat baca anak usia dini melalu Program Gernas Baku. Teori yang digunakan dalam penelitian ini adalah Minat Baca, Pengelola Lembaga PAUD, serta Gernas Baku. Dalam penelitian ini peneliti menggunakan metode deskriptif dengan pendekatan kualitatif. Sumber data dalam penelitian ini didapat dari sample penelitian yang diambil dari populasi di Pos PAUD Kasih Bunda yaitu 1 orang Pengelola, 3 Orang Tua, dan 3 peserta didik. Hasil penelitian menunjukkan bahwa Program Gernas Baku yang diterapkan di Pos PAUD Kasih Bunda memang dapat menumbuhkan minat baca anak. Minat baca anak usia dini terlihat dari rasa senang anak terhadap buku.
\end{abstract}

Kata Kunci: Minat baca, Pengelola Lembaga PAUD, Gernas Baku 
130 Sukmandinata, Peran Pengelola PAUD Dalam Menumbuhkan Minat Baca Anak Usia Dini Melalui Program Gerakan Nasional Orang Tua Membacakan Buku (Gernas Baku)

How to Cite: Sukmandinata, Y. (2020). Peran Pengelola PAUD Dalam Menumbuhkan Minat Baca Anak Usia Dini Melalui Program Gerakan Nasional Orang Tua Membacakan Buku (Gernas Baku). Comm-Edu (Community Education Journal) 3 (2), 129-137.

\section{PENDAHULUAN}

Tingkat minat baca anak usia dini di Indonesia masih sangat rendah. Hasil Survey Programme for internasional Student Assesment (PISA) pada tahun 2015 menunjukkan bahwa Indonesia berada di urutan ke-64 dari 72 Negara. Menurut survey Badan Pusat Statistik (BPS) tahun $2015,91,4 \%$ anak usia sekolah lebih suka menonton telivisi dan 13,11\% yang suka membaca (Sukiman, 2018). Kondisi ini bisa jadi dikarenakan tidak pedulinya orang tua akan aktivitas membaca. Banyak anak yang kedua orang tuanya sibuk bekerja sehingga mereka tidak lagi mempunyai cukup waktu dan energi untuk mendekatkan anaknya dengan buku, atau dikarenakan seiring berkembangnya jaman dengan kecanggihan teknologi yang berkembang pesat seperti teknologi telekomunikasi, informatika, dan broadcasting yang menyebabkan masyarakat lebih senang menonton televisi dibandingkan dengan membaca.

Membaca dapat diibaratkan membuka jendela dunia, karena dengan membaca dapat memperluas wawasan kita. Oleh sebab itu perlu adanya upaya menumbuhkan minat baca terutama pada anak usia dini. Grellt dalam (Muchlison \& dkk, 1992) mengatakan: "Kegiatan membaca adalah semacam dialog antara pembaca dan penulis, tanpa kecuali anak usia dini, dan kemampuan membaca mempengaruhi kemampuan berbicara, sehingga dapat dikatakan bahwa membaca merupakan aspek kebahasaan yang berfungsi sebagai pintu awal dalam membuka cakrawala berpikir seseorang". Pembinaan minat baca pada usia dini akan lebih efektif bila orang tua berperan serta secara aktif dalam mendorong, membimbing anaknya untuk gemar mebaca. Orang tua harus memastikan bahwa kecintaan akan membaca adalah tujuan pendidikan yang terpenting bagi anaknya. Upaya orang tua akan lebih optimal apabila didukung oleh pihak lain. Dari pihak pengelola Lembaga PAUD misalnya. Dilansir dari situs jurnalmahasiswa.unesa.ac.id, penelitian yang dimuat Journal PAUD teratai, Asri dalam (Hidayati, 2013) menjelaskan bahwa: "Upaya meningkatkan minat baca anak yang utama menjadi tanggung jawab orang tua sebelum anak memasuki dunia pendidikan. Setelah masuk TK, maka kewajiban itu menjadi tugas para guru. Guru mempunyai peran yang sangat penting pula terhadap peningkatan minat baca anak, karena guru akan menjadi figure tuntunan bagi anak selama berada dalam pendidikan formal".

Menumbuhkan minat baca khususnya pada anak usia dini yang memiliki konsentrasi masih belum stabil dan daya fokusnya tidak bertahan lama menjadi tantangan tersendiri bagi civitas akademika di lingkungan PAUD. Akan tetapi sebagai guru PAUD merupakan suatu tantangan yang harus dihadapi sebagai bentuk profesionalisme sebagai seorang pendidik yang harus berdedikasi tinggi terhadap kemajuan pendidikan anak usia dini. Membaca biasa dilakukan atau didaptakan oleh anak Taman Kanak-kanak yaitu diusia sekitar 4-6 tahun. Anak-anak yang memperoleh keterampilan membaca akan lebih mudah menyerap informasi dan pengetahuan pada waktu-waktu selanjutnya dalam kehidupan anak itu sendiri. Durkin dalam (Dhieni \& dkk, 2007) menyatakan: "tidak ada efek negatif pada anak-anak dari membaca dini. Anak-anak yang telah diajar membaca sebelum masuk sekolah dasar umumnya lebih maju di sekolah dari anakanak yang belum pernah memperoleh membaca dini". Masa anak-anak merupakan masa yang tepat untuk menanamkan sebuah kebiasaan, dan kebiasaan ini akan terbawa hingga anak tumbuh dewasa. Apabila sejak dini anak sudah terbiasa membaca, maka kebiasaan membaca akan terbawa hingga dewasa. 
Pada saat ini pemerintah memberikan perhatian terhadap kurangnya minat baca anak pada usia dini. Maka dari itu pemerintah berkolaborasi dengan pegiat peduli pendidikan anak usia dini, perguruan tinggi, dan dunia usaha dalam rangka meningkatkatkan partisipasi keluarga dan Lembaga PAUD untuk menumbuhkan budaya membaca dengan membuat Program Gerakan Nasional Orang Tua Membacakan Buku (GERNAS BAKU). Gernas Baku adalah gerakan untuk mendukung inisiatif dan peran keluarga dalam meningkatkan minat baca anak melalui pembiasaan dirumah, di satuan PAUD, dan di Masyarakat.

Dari permasalahan diatas, maka permasalahan yang ingin diteliti oleh peneliti yaitu: Bagaimana upaya Pengelola Lembaga PAUD Kasih Bunda dalam menumbuhkan minat baca anak pada usia dini melalui Program Gernas Baku?

Sedangkan tujuan dari dilakukannya penelitian ini yaitu: Mengetahui upaya Pengelola Lembaga PAUD Kasih Bunda dalam menumbuhkan minat baca anak pada usia dini melalui Program Gernas Baku.

\section{LANDASAN TEORI}

\section{Minat Baca}

Minat baca adalah keinginan atau kecenderungan hati yang tinggi (gairah) untuk membaca (Siregar, 2004). Hal tersebut sejalan dengan pendapat Darmono yang menyatakan bahwa minat baca merupakan kecenderungan jiwa yang mendorong seseorang berbuat sesuatu terhadap membaca (Darmono, 2001).Membaca merupakan salah satu dari empat keterampilan berbahasa, yaitu keterampilan menyimak/ mendengarkan (listening skills), dan keterampilan berbicara (speaking skills), keterampilan membaca (reading skills), dan keterampilan menulis (writing skills). Sedangkan membaca menurut Hodgson dalam (Tarigan, 2015) adalah suatu proses yang dilakukan serta dipergunakan oleh pembaca untuk memperoleh pesan, yang hendak disampaikan oleh penulis melalui media kata-kata/ bahasa tulis. Sedangkan dari segi linguistik, membaca adalah suatu proses penyandian kembali dan pembacaan sandi, berlainan dengan berbicara dan menulis yang justru melibatkan penyandian. Dilansir dari situs jurnal.iain-padangsidimpuan.ac.id, penelitian yang dimuat Journal Logaritma Jurnal ilmu-ilmu Pendidikan dan Sains mengungkapkan bahwa: "Menumbuhkan minat membaca perlu dibiasakan sejak dini, yakni mulai dari anak mengenal huruf. Jadikanlah kegiatan membaca sebagai suatu kebutuhan dan menjadi hal yang menyenangkan. Membaca dapat dilakukan dimana saja dan kapan saja asalkan ada keinginan, semangat, dan motivasi yang diberikan oleh orang tuanya (Ikawati, 2015)".

Menumbuhkan minat baca anak pada usia dini perlu dilakukan agar dapat menghasilkan sumber daya manusia yang berkualitas tinggi. Pada dasarnya, anak usia dini (4-6 tahun) yang berada di PAUD tidak diwajibkan untuk bisa membaca, namun pada usia dini minimal anak mengenal buku agar anak menjadi terbiasa untuk merasakan, dan melihat keberadaan buku selain mendengarkan cerita didalamnya. Maka dari itu, lebih penting menumbuhkan minat baca pada anak usia dini daripada mengharuskan anak dapat cepat bisa membaca. Buku memiliki andil yang besar untuk menambah wawasan yang besar. Dilansir dari situs https://ejournal.unib.ac.id/index.php/potensia, penelitian yang dimuat Jurnal Ilmiah Potensia, 2019, Vol. 4 (2) 115-120 menyatakan bahwa: Adanya minat baca dari dalam diri seorang anak dapat ditandai ketika anak tersebut mengungkapkan kegemarannya dan cenderung lebih tertarik serta menyukai kegiatan membaca (Sumitra \& Sumini, 2019)". Adapun indikatorndikator minat baca anak menurut (Dhieni, 2010: 3.18): 1) anak sudah mulai senang atau gemar pada buku. 2) Anak mulai mengeja berbagai tulisan yang dimuat di majalah, Kotak susu, Pasta Gigi, Surat Kabar atau bacaan lainnya. 3) Anak mulai bertanya arti dan maksud suatu gambar. 
132 Sukmandinata, Peran Pengelola PAUD Dalam Menumbuhkan Minat Baca Anak Usia Dini Melalui Program Gerakan Nasional Orang Tua Membacakan Buku (Gernas Baku)

4) Anak membaca hal-hal yang dilihat dalam perjalanan. Keuntungan dari anak jika dibiasakan membaca sejak dini yaitu: (1) Menambah kosa kata anak, (2) Meningkatkan kemampuan pemahaman, (3) Menentukan pola pikir anak, (4) Meningkatkan daya imajinasi anak, (5) Melatih kepandaian berkomunikasi.

\section{Pengelola Lembaga PAUD}

Pengelola Lembaga PAUD adalah pihak yang bertanggung jawab atas penyelenggaraan PAUD yang antara lain terkait dengan pengelolaan lembaga, peserta didik, pendidik dan tenaga kependidikan. Adapun tugas pokok dan fungsi pengelola PAUD adalah sebagai berikut: (1) Menyusun rencana strategis dan rencana program PAUD, (2) Memberikan pengarahan tentang tumbuh kembang anak usia dini, (3) Memberikan pembinaan kurikulum PAUD yang berlaku, (4) Melakukan pembinaan diktatik, metodik, secara umum maupun khusus, (5) Mengarahkan guru membuat perencanaan pembelajaran, (6) Memberikan contoh pengelolaan proses belajar mengajar, (7) Membina penggunaan standar operasional prosedur (SOP) dan pelaporan perkembangan anak, (8) Memberikan pemahaman kepada guru dalam mengatasi berbagai persoalan anak usia dini (bimbingan konseling), (9) Membina kegiatan administrasi kelembagaan sekolah PAUD, (10) Membuat perencanaan anggaran, (11) Melakukan kegiatan supervise internal, (12) Menjalin kerjasama dengan orang tua dan lembaga-lembaga lain yang terkait, (13) Memberikan berbagai alternative inovasi dan pengembangan pembelajaran PAUD, (14) Membuat kegiatan promosi lembaga PAUD yang dipimpinnya.

\section{Gerakan Nasional Orang Tua Membacakan Buku (GERNAS BAKU)}

Gernas Baku adalah gerakan untuk mendukung inisiatif dan peran keluarga dalam meningkatkan minat baca anak melalui pembiasaan di rumah, di satuan PAUD, dan di masyarakat. Gernas baku bertujuan untuk: (1) Membiasakan orang tua membacakan buku bersama anak, (2) Mempererat hubungan sosial-emosi antara anak dan orang tua, (3) Menumbuhkan minat baca anak sejak dini. Gernas baku melibatkan orang tua, warga sekolah, serta masyarakat. Gernas Baku dapat dilaksanakan di rumah, satuan PAUD, serta Komunitas. Gernas Baku resmi dilaksanakan serentak di Indonesia pada tanggal 05 Mei 2018. Gernas Baku telah dimulai program dan pengkajiannya sejak bulan Februari 2018 melalui kegiatan bulan sosialisasi dan kampanye serta seminar. Implementasi Gernas Baku antara lain: (1) Kegiatan dirumah, yaitu: orang tua belajar memahami kemampuan membaca anak (sesuai tahap perkembangan), orang tua belajar memahami teknik menarik minat/ kesenangan anak untuk membaca, orang tua belajar memahami teknik membacakan buku untuk anak (sesuai tahap perkembangan), Orang tua belajar membiasakan membacakan buku/ bacaan, atau bercerita dengan anak. (2) Kegiatan di Satuan Pendidikan (Komite PAUD dan paguyuban orang tua murid), yaitu: (1) Menyelenggarakan kelas orang tua dengan tema menumbuhkan minat baca anak, menyelenggarakan kegiatan kelas inspirasi dengan tema manfaat senang membaca, mempersiapkan pelaksanaan gerakan orang tua membacakan buku, Melibatkan orang tua menjadi sukarelawan untuk membacakan buku di dalam kelas, melibatkan orang tua untuk membantu mengelola perpustakaan/ pojok buku keluarga, membacakan buku untuk anaknya masing-masing. (Sukiman, 2018)

\section{METODE PENELITIAN}

Dalam penelitian ini peneliti menggunakan metode deskriptif dengan pendekatan kualitatif. Menurut Creswell dalam (Darmadi, 2014) mengatakan bahwa: "pendekatan kualitatif adalah suatu proses penelitian pemahaman yang berdasarkan pada metodologi yang menyelidiki suatu fenomena sosial dan masalah manusia. Sedangkan metode deskriptif adalah metode yang 
mendeskripsikan atau menggambarkan suatu fenomena atau gejala yang dihubungkan dengan teori-teori yang relevan dengan teori yang digunakan pada variabel penelitian.

Instrumen dalam penelitian ini adalah peneliti sendiri karena dalam penelitian kualitatif segala sesuatu yang akan dicari dari obyek penelitian belum jelas dan pasti masalahnya, sumber datanya, hasil yang diharapkan semuanya belum jelas. Peneliti terjun langsung ke lapangan untuk menetapkan fokus penelitian, memilih informan sebagai sumber data, melakukan pengumpulan data, menilai kualitas data, analisis data, menafsirkan data dan membuat kesimpulan atas semuanya. Teknik pengumpulan data melalui wawancara, observasi, dan dokumentasi. Prosedur pengolahan data merupakan proses yang sangat penting, oleh karena itu harus dilakukan secara benar. Data yang diperoleh dianalisa, dengan maksud untuk menjawab rumusan masalah yang sudah ditetapkan.

Teknik analisis data dilakukan bersamaan dengan pengumpulan data. Analisis data kualitiatif menurut Spradley dalam (Sugiyono, 2017) dilakukan secara berurutan, melalui proses analisis domain, taksonomi, kompenensial, dan tema budaya. Peneliti melakukan analisis data menggunakan analisis data selama di lapangan model Spradley yang membagi analisis data kedalam beberapa tahapan. Setelah memasuki lapangan, peneliti menetapkan seseorang informan kunci. Setelah itu peneliti melakukan wawancara kepada informan tersebut, dan mencatat hasil wawancara. Setelah itu perhatian peneliti pada obyek penelitian dan memulai mengajukan pertanyaan deskriptif, dilanjutkan dengan analisis terhadap wawancara. Berdasarkan hasil dari analisis wawancara selanjutnya peneliti melakukan analisis domain. kemudian peneliti menentukan fokus dan melakukan analisis taksonomi. Berdasarkan analisis taksonomi, selanjutnya peneliti mengajukan pertanyaan kontras, yang dilanjutkan dengan analisis kompensional. Selanjutnya peneliti menemukan tema-tema budaya. Berdasarkan temuan tersebut, peneliti menulis laporan kualitatif.

Penelitian ini dilakukan di Pos PAUD Kasih Bunda, Kp. Muara Rw 10 Desa Sugihmukti Kecamatan Pasirjambu Kabupaten Bandung. Populasi adalah jumlah keseluruhan dari satuansatuan atau individu-individu yang karakteristiknya hendak diteliti, dan satuan-satuan tersebut dinamakan unit analisis, yang dapat berupa orang-orang, institusi-institusi, benda-benda, fenomena alam, dan sebagainya. Sedangkan sampel adalah sebagian dari jumlah objek/ subjek penelitian yang akan diteliti (Darmadi, 2014). Yang menjadi populasi penelitian ini adalah 1 orang ketua Pengelola Lembaga PAUD Kasih Bunda, 3 orang tenaga pendidik, orang tua peserta didik yang berjumlah 22 orang, serta peserta didik kelas B kelompok usia 5-6 tahun yang berjumlah 22 orang. Kemudian dari semua jumlah populasi peneliti mengambil 1 orang ketua pengelola lembaga PAUD Kasih Bunda, 3 orang orang tua peserta didik, dan 3 orang peserta didik secara purposive dan snowball untuk menentukan siapa saja yang dapat dijadikan sampel sumber data tersebut.

\section{HASIL DAN PEMBAHASAN}

\section{Hasil}

Hal pertama yang dilakukan Pengelola Lembaga PAUD Kasih Bunda untuk meningkatkan minat baca anak pada usia dini ialah dengan mengikuti Seminar Nasional yang dilaksanakan pada tanggal 05 Mei 2018. Seminar tersebut adalah seminar program Pemerintah yakni 
Program Gerakan Nasional Orang Tua Membacakan Buku (GERNAS BAKU). Setelah itu, Pengelola menerapkan hasil seminar yang diikutinya tersebut dengan menyediakan pojok buku dan berbagai macam buku bacaan untuk anak usia dini. Buku-buku yang disediakan pengelola Lembaga PAUD Kasih Bunda didapatkan dengan cara pengelola membeli sendiri, dan beberapa buku didapat dari sumbangan para orang tua. Dengan ketersediaan buku tersebut orang tua diberi arahan agar dapat meluangkan waktu untuk membacakan buku kepada anaknya yang dapat dilakukan di rumah maupun di lembaga PAUD.

Pada awal penerapan program Gernas Baku di pos PAUD Kasih Bunda, pengelola menetapkan jadwal orangtua membacakan buku kepada anak secara serentak yang dilakukan sekali dalam satu minggu, yaitu pada hari rabu selama 15-30 menit di waktu istirahat pukul 15:00-15:30. Hal tersebut berjalan di tahun 2018. Pada saat ini, hal tersebut sudah tidak dilaksanakan dikarenakan pengelola lembaga merasa bahwa saat ini anak sudah memiliki minat baca tanpa harus selalu dibacakan oleh orang tua di Lembaga PAUD. Minat baca anak terlihat dari ketertarikan mereka terhadap buku pada saat pelaksanaan recalling yang dilakukan setiap hari kamis dan jumat. Pengelola membebaskan anak untuk bermain, atau melakukan aktivitas sesuai keinginan anak. Berdasarkan hasil wawancara dengan Ibu Irma selaku ketua pengelola, dari ke-12 anak kelas B kelompok usia 5-6 tahun terdapat 3 anak yang menarik perhatian yaitu Habib Bukhori, Perlita Queena, Sidki Al Khoir. Ke-3 anak tersebut paling dominan menunjukan memiliki minat baca terlihat dari: (1) Rasa senang yang ditunjukkan dengan perasaan anak yang terlihat dari mimik muka senang ketika melihat buku, (2) Tertarik, ditunjukkan dengan anak mengambil buku kemudian membuka dan membaca buku dengan sendirinya, (3) Berinisiatif, pada waktu bermain anak lebih suka membaca di pojok buku dan ketika diberikan berbagai mainan anak lebih suka memilih buku, (4) Perhatian, anak memperhatikan buku, membuka-buka buku kemudian membaca buku. Untuk menambah informasi mengenai minat baca yang dimiliki Habib Bukhori, Perlita Queena, Sidki Al Khoir, peneliti melakukan wawancara dengan orang tua dari masing-masing anak terkait aktivitas anak dirumah yang menunjukkan minat baca anak.

Hasil wawancara bersama Ibu Teti Suryati (ibu dari Habib Bukhori) menyatakan bahwa beliau rutin meminjam buku setiap harinya dari pojok buku untuk dibacakan kepada anaknya sebelum tidur karena sang anak selalu meminta dibacakan cerita/ dongeng dari buku sebelum ia tidur serta untuk membantu anaknya mengenal huruf. Sedangkan Ibu Ai Sumiati menyatakan bahwa beliau meminjam buku 2 kali dalam satu minggu untuk dibaca oleh sang anak dirumah dengan tujuan meningkatkan kemampuan anak dalam membaca karena Perlita sudah mulai bisa mengeja huruf menjadi kata-kata. Kegiatan belajar membaca dirumah dilakukan sebelum anak tidur selama 10-15 menit.

Berdasarkan hasil wawancara terakhir bersama Ibu Rita Nurhayati Sidiq Al Khoir adalah anak yang suka melihat buku-buku bergambar. Di rumah, Sidiq dalam setiap harinya diajak oleh sang ibu membaca buku walau hanya dalam waktu 5-10 menit sebelum sidiq pergi bermain. Untuk anak-anak selain Habib Bukhori, Perlita Queena, Sidki Al Khoir, mereka juga dirasa sudah memiliki minat baca karena dalam waktu recalling mereka juga pergi ke pojok buku, namun waktu bermain-main masih lebih banyak dibanding dengan membaca. Ibu Irma tidak mempermasalahkan hal tersebut, karena Ibu Irma selaku pengelola Lembaga PAUD memiliki prinsip jikalau menumbuhkan minat baca pada anak haruslah tumbuh dari keinginan anak sendiri tanpa harus dipaksa.

\section{Pembahasan}


Upaya meningkatkan minat baca anak pada usia dini, Pemerintah berkolaborasi dengan pegiat peduli pendidikan anak usia dini, perguruan tinggi, dan dunia uasaha dalam rangka meningkatkatkan partisipasi keluarga dan Lembaga PAUD untuk menumbuhkan budaya membaca dengan membuat Program Gerakan Nasional Orang Tua Membacakan Buku (GERNAS BAKU). Sebagai pegiat peduli pendidikan anak usia dini, Pengelola PAUD Kasih Bunda turut serta berupaya meningkatkan minat baca anak pada usia dini. Hal pertama yang dilakukan Pengelola Lembaga PAUD Kasih Bunda untuk meningkatkan minat baca anak pada usia dini ialah dengan mengikuti Seminar Nasional yang dilaksanakan pada tanggal 05 Mei 2018. Seminar tersebut adalah seminar program Pemerintah yakni Program Gerakan Nasional Orang Tua Membacakan Buku (GERNAS BAKU). Setelah itu, Pengelola menerapkan hasil seminar yang diikutinya tersebut dengan menyediakan pojok buku dan berbagai macam buku bacaan untuk anak usia dini. Buku-buku yang disediakan pengelola Lembaga PAUD Kasih Bunda didapatkan dengan cara pengelola membeli sendiri, dan beberapa buku didapat dari sumbangan para orang tua.

Dengan ketersediaan buku tersebut orang tua diberi arahan agar dapat meluangkan waktu untuk membacakan buku kepada anaknya yang dapat dilakukan di rumah maupun di lembaga PAUD sesuai dengan tujuan Gerna Baku yaitu: (1) Membiasakan orang tua membacakan buku bersama anak, (2) Mempererat hubungan sosial-emosi antara anak dan orang tua, (3) Menumbuhkan minat baca anak sejak dini. (Sukiman, 2018). Hasilnya, dari ke-12 anak kelas B kelompok usia 5-6 tahun terdapat 3 anak yang menarik perhatian yaitu Habib Bukhori, Perlita Queena, Sidki Al Khoir yang paling dominan menunjukan memiliki minat baca terlihat dari: (1) Rasa senang yang ditunjukkan dengan perasaan anak yang terlihat dari mimik muka senang ketika melihat buku, (2) Tertarik, ditunjukkan dengan anak mengambil buku kemudian membuka dan membaca buku dengan sendirinya, (3) Berinisiatif, pada waktu bermain anak lebih suka membaca di pojok buku dan ketika diberikan berbagai mainan anak lebih suka memilih buku, (4) Perhatian, anak memperhatikan buku, membuka-buka buku kemudian membaca buku. Hal tersebut seiring dengan indakot minat baca menurut (Dhieni, 2010: 3.18): 1) anak sudah mulai senang atau gemar pada buku. 2) Anak mulai mengeja berbagai tulisan yang dimuat di majalah, Kotak susu, Pasta Gigi, Surat Kabar atau bacaan lainnya. 3) Anak mulai bertanya arti dan maksud suatu gambar. 4) Anak membaca hal-hal yang dilihat dalam perjalanan. Hal tersebut juga dikuatkan dengan hasil wawancara bersama orang tua ke-3 anak tersebut terkait aktivitas yang menunjukkan minat baca anak.

Untuk anak-anak selain Habib Bukhori, Perlita Queena, Sidki Al Khoir, mereka juga dirasa sudah memiliki minat baca karena dalam waktu recalling mereka sesekali juga pergi ke pojok buku, namun waktu bermain-main masih lebih banyak dibanding dengan membaca. Ibu Irma tidak mempermasalahkan hal tersebut, karena Ibu Irma selaku pengelola Lembaga PAUD memiliki prinsip jikalau menumbuhkan minat baca pada anak haruslah tumbuh dari keinginan anak sendiri tanpa harus dipaksa. Pada dasarnya, anak usia dini (4-6 tahun) yang berada di PAUD tidak diwajibkan untuk bisa membaca, namun pada usia dini minimal anak mengenal buku agar anak menjadi terbiasa untuk merasakan, dan melihat keberadaan buku selain mendengarkan cerita didalamnya. Maka dari itu, lebih penting menumbuhkan minat baca pada anak usia dini daripada mengharuskan anak dapat cepat bisa membaca. Buku memiliki andil yang besar untuk menambah wawasan yang besar. Dilansir dari situs https://ejournal.unib.ac.id/index.php/potensia, penelitian yang dimuat Jurnal Ilmiah Potensia, 2019, Vol. 4 (2) 115-120 menyatakan bahwa: Adanya minat baca dari dalam diri seorang anak dapat ditandai ketika anak tersebut mengungkapkan kegemarannya dan cenderung lebih tertarik serta menyukai kegiatan membaca (Sumitra \& Sumini, 2019)”. 
136 Sukmandinata, Peran Pengelola PAUD Dalam Menumbuhkan Minat Baca Anak Usia Dini Melalui Program Gerakan Nasional Orang Tua Membacakan Buku (Gernas Baku)

\section{KESIMPULAN}

Berdasarkan pemaparan hasil penelitian yang telah penulis uraikan diatas, dapat diambil kesimpulan bahwa Pengelola Lembaga PAUD Kasih Bunda dapat menumbuhkan minat baca anak usia dini melalui keikutsertaannya berkolaborasi dengan Pemerintah melalui program Gerakan Orang Tua Membacakan Buku (GERNAS BAKU). Pelaksanaan program tersebut dilaksanakan dengan cara Pengelola Lembaga PAUD menyediakan pojok buku dan berbagai macam buku bacaan untuk anak dengan bantuan para orang tua murid yang berperan aktif membacakan buku kepada anaknya dirumah dan memotivasi agar memiliki minat baca. Tumbuhnya minat baca pada anak terlihat dari 3 anak kelas B Kelompok usia 5-6 tahun yang paling dominan menunjukan memiliki minat baca terlihat dari: (1) Rasa senang yang ditunjukkan dengan perasaan anak yang terlihat dari mimik muka senang ketika melihat buku, (2) Tertarik, ditunjukkan dengan anak mengambil buku kemudian membuka dan membaca buku dengan sendirinya, (3) Berinisiatif, pada waktu bermain anak lebih suka membaca di pojok buku dan ketika diberikan berbagai mainan anak lebih suka memilih buku, (4) Perhatian, anak memperhatikan buku, membuka-buka buku kemudian membaca buku.

\section{DAFTAR PUSTAKA}

Darmadi, H. (2014). Metode Penelitian dan Sosial. Bumi Khatulistiwa: Alfabeta.

Darmono. (2001). Manajemen Perpustakaan Sekolah. Jakarta: Grasindo.

Dhieni, N. (2010). Metode Pengembangan Bahasa. Jakarta: Universitas Terbuka.

Dhieni, N., \& dkk. (2007). Mengikat Makna: Kiat-kiat Ampuh untuk Melejitkan Kemauan Plus Kemampuan Membaca dan Menulis Buku. Bandung: Kaifa.

Hidayati, N. (2013). Peningkatan Minat Baca Melalui Storrytelling Anak Kelompok B TK AlMutaqqien Surabaya. PAUD Teratai, 1-6.

Ikawati, E. (2015). Upaya Meningkatkan Minat Membaca Pada Anak Usia Dini. Logaritma: Jurnal Ilmu-ilmu Pendidikan dan Sains, 1-12.

Muchlison, \& dkk. (1992). Materi Pokok Bahasa Indonesia 3. Jakarta: Depdikbud.

Siregar, A. R. (2004). Perpustakaan Energi Pembangunan Bangsa. Medan: Universitas Sumatra Utara.

sugiyono. (2017). Metode Penelitian Kuantitatif, Kualitatif, dan R\&D. Bandung: Alfabeta.

Sukiman. (2018). Panduan Pelaksanaan Gerakan Nasional Orang Tua Membacakan Buku (GERNAS BAKU). Jakarta: Direktorat Pembinaan Pendidikan Keluarga, Direktorat Pendidikan Anak Usia Dini dan Pendidikan Masyarakat, Kementrian Pendidikan dan Kebudayaan.

Sumitra, A., \& Sumini, N. (2019). Peran Guru dalam Mengembangkan Kemampuan Minat Baca Anak Usia Dini Melalui Metode Read Aloud. Jurnal Ilmiah Potensia Vol. 4 (2), 115-120. 
Tarigan, H. G. (2015). Membaca sebagai Suatu Keterampilan Berbahasa. Bandung: CV. Angkasa. 